\title{
An Azospira oryzae (syn Dechlorosoma suillum) Strain That Reduces Selenate and Selenite to Elemental Red Selenium
}

\author{
William J. Hunter \\ United States Department of Agriculture, Agricultural Research Service, 2150-D Centre Ave, Fort Collins, CO 80526-8119, USA
}

Received: 6 September 2006 / Accepted: 9 December 2006

\begin{abstract}
A bacterium that reduces the soluble selenium oxyanions, selenate and selenite, to insoluble elemental red selenium $\left(\mathrm{Se}^{0}\right)$ was isolated from a laboratory reactor developed to remove selenate from groundwater. Gene sequence alignment of the 16S rRNA allowed identification of the isolate as Azospira oryzae. Biochemical and morphologic characterization confirm the identification. The isolate reduces selenate and selenite to $\mathrm{Se}^{0}$ under microaerophilic and denitrifying conditions but not under aerobic conditions. It does not use selenate or selenite as terminal $\mathrm{e}^{-}$donors. Se oxyanion reduction causes the formation of Se nanospheres that are $0.25 \pm 0.04 \mu \mathrm{m}$ in diameter. Nanospheres may be associated with the cells or free in the medium. The enzymatic activity associated with the reduction of selenate has a molecular mass of approximately $500 \mathrm{kD}$, and the enzymatic activity associated with the reduction of selenite has a mass of approximately $55 \mathrm{kD}$. Selenite reduction was inhibited by tungsten. The molecular masses of these activities were different from those associated with the reduction of dimethylsulfoxide, sulfate, and nitrite. This bacterium, or perhaps its enzymes or DNA, might be useful for the remediation of waters contaminated with Se oxyanions.
\end{abstract}

Environmental selenium exists in several different oxidation states. Under oxic conditions, the oxyanions selenate $\left(\mathrm{Se}^{6+}\right)$ and selenite $\left(\mathrm{Se}^{4+}\right)$ predominate, whereas elemental selenium $\left(\mathrm{Se}^{0}\right)$ and selenide $\left(\mathrm{Se}^{2-}\right)$ are more common under anoxic conditions. The form in which selenium exists plays a role in its toxicity and bioavailability. Both selenate $\left(\mathrm{SeO}_{4}{ }^{-2}\right)$ and selenite $\left(\mathrm{SeO}_{3}{ }^{-2}\right)$ can be toxic, and both are highly soluble in water and thus available for biologic uptake. In contrast, $\mathrm{Se}^{0}$, because it is only sparingly soluble in water and has low bioavailability, does not present a toxicity problem. Methylation also decreases selenium toxicity; dimethylselenide (DMSe) and dimethyldiselenide (DMDSe) are much less toxic than are the oxyanions [7].

Microorganisms convert Se from one form to another, and they play a key role in the environmental transformation of $\mathrm{Se}$. $\mathrm{SeO}_{4}{ }^{-2}$ and $\mathrm{SeO}_{3}{ }^{-2}$ are often encountered as contaminants of surface waters and ground waters, and the reduction of these compounds to

Correspondence to: W.J. Hunter; email: william.hunter@ars.usda.gov less toxic forms by microbial action represents an important emerging bioremediation concept. Only a few microorganisms that reduce $\mathrm{Se}$ oxyanions to $\mathrm{Se}^{0}$ have been studied. This article describes the characterization and identification of a new bacterial isolate that reduces $\mathrm{SeO}_{4}{ }^{-2}$ and $\mathrm{SeO}_{3}{ }^{-2}$ to $\mathrm{Se}^{0}$.

\section{Materials and Methods}

Media. Media were NWRI [8], tryptone-yeast extract (TY) media (8g/1 tryptone, $5 \mathrm{~g} / 1$ yeast extract, and $2.5 \mathrm{~g} / \mathrm{l} \mathrm{NaCl}$ ); and a $\mathrm{N}-2$ hydroxyethylpiperazine- $\mathrm{N}^{\prime}$-ethanesulfonic acid and 2-(N-morpholino) ethanesulfonic acid (HM) salts media with $30 \mathrm{mM}$ sodium acetate as substrate [11].

Isolation, identification, and characterization of the isolate. The bacterium, designated the N1 strain, was isolated from a laboratory bioreactor that effectively reduced selenate to $\mathrm{Se}^{0}[10]$. Cell and colony morphology was determined after growth on TY agar for 6 days at $28^{\circ} \mathrm{C}$, and biochemical characteristics were determined with API-20E test strips (bioMérieux Inc., Marcy L'Etoile, France) incubated for 48 hours. Also, cells were submitted to MIDI Labs (Newark, DE) for 16S rRNA (1540-bp) gene sequence determination. The sequence (GenBank accession number DQ863512) was analyzed on the BLAST database at the National Center for Biotechnology 
Information. Phylogenetic analyses and neighbor-joining tree construction were made using the MEGA 3.1 computer program (http://www.megasoft.net) [13]. Sequences were exported from the BLAST database and aligned using the ClustalW option within the MEGA 3.1 program. The cells gram reaction was determined by potassium hydroxide procedure [4].

Selenite and selenate as electron $\left(\mathrm{e}^{-}\right)$acceptors. Studies were conducted as described earlier [11] with $\mathrm{CH}_{3} \mathrm{COONa}$ as substrate and $\mathrm{Na}_{2} \mathrm{SeO}_{4}, \mathrm{Na}_{2} \mathrm{SeO}_{3}, \mathrm{NaNO}_{3}, \mathrm{Na}_{2} \mathrm{SeO}_{4}+\mathrm{NaNO}_{3}$, or $\mathrm{Na}_{2} \mathrm{SeO}_{3}+$ $\mathrm{NaNO}_{3}$ as e ${ }^{-}$donors. $\mathrm{Na}_{2} \mathrm{SeO}_{4}$ and $\mathrm{NaNO}_{3}$ were supplied at $10 \mathrm{mM}$ and $\mathrm{Na}_{2} \mathrm{SeO}_{3}$ at $4 \mathrm{mM}$. Growth (turbid) was estimated visually.

Colony size studies. The effect of selenate and selenite on growth was determined as previously described [11] by growing the isolate on NWRI agar supplemented with $\mathrm{Na}_{2} \mathrm{SeO}_{4}$ or $\mathrm{Na}_{2} \mathrm{SeO}_{3}$ as indicated. The effects of $\mathrm{NaClO}_{3}$ and $\mathrm{NaNO}_{3}$ were determined in the same manner with cells incubated on TY agar under a $1 \%$ oxygen atmosphere.

Analysis. Selenate and selenite were measured by ion chromatography. Buffer was $0.3 \mathrm{mM} \mathrm{NaHCO} 3$ and $0.99 \mathrm{mM}$ $\mathrm{Na}_{2} \mathrm{CO}_{3}$; flow was $1.25 \mathrm{ml} \mathrm{min}^{-1}$; and the column was a $250 \times 2.6$ mm Serasep AN-1 column (Alltech, Deerfield, IL).

Preparation of cell-free extract and electrophoresis. Cells were grown under air for approximately 6 days at $28^{\circ} \mathrm{C}$ and $100 \mathrm{rpm}$ in sealed 500-ml bottles. Media was TY $(300 \mathrm{ml})$ containing $40 \mathrm{mM}$ $\mathrm{NaNO}_{3}, 40 \mathrm{mM} \mathrm{Na}_{2} \mathrm{SeO}_{4}$, and $10 \mathrm{mM} \mathrm{MoO}_{3}$. Cells, $500 \mathrm{ml}$, were spun at $10,000 \times \mathrm{g}$ for 20 minutes, and the pellet was resuspended in $8 \mathrm{ml}$ ice-cold $25 \mathrm{mM}$ Tris and $192 \mathrm{mM}$ glycine buffer (pH 8.3) containing $1 \mathrm{mM} 4$-(2-aminoethyl) benzenesulfonyl fluoride and $0.01 \%$ Triton X100. Cells were homogenized with the aid of a French pressure cell press operated at $120 \mathrm{MPa}$, and the homogenate was spun at $22,500 \times \mathrm{g}$ for 20 minutes to remove unbroken cells. The cell-free extract was concentrated approximately five-fold with a $10-\mathrm{kD}$ molecular weight cutoff filter (Nanosep; Pall Life Sciences, Ann Arbor, MI) and spun at $12,000 \times \mathrm{g}$ for 50 minutes. Proteins (approximately $60 \mu \mathrm{g} / \mathrm{lane}$ ) in the concentrate were separated on $3 \%$ to $8 \%$ and $14 \%$ nondenaturing polyacrylamide electrophoresis gels. After electrophoresis, gels were transferred to a helium-filled glove bag and incubated in $25 \mathrm{ml} 50 \mathrm{mM}$ HEPES buffer ( $\mathrm{pH} 7.5$ ) containing $0.6 \mathrm{mM}$ methyl viologen (MV) reduced with $0.5 \mathrm{mg} \mathrm{Na} \mathrm{S}_{2} \mathrm{O}_{4}$ for approximately 15 minutes. Buffer was removed, and the oxidatively reduced gels were incubated with 10 $\mathrm{ml}$ buffer containing $100 \mathrm{mM}$ selenate, $\mathrm{NaNO}_{3}, \mathrm{NaNO}_{2}$, dimethylsulfoxide (DMSO), or $\mathrm{NaSO}_{4}$. Selenite reductase activity, or the presence of the enzyme protein, was detected by the formation of clear bands in the deep blue MV-stained gels [14]. Selenite reductase was visualized as precipitated $\mathrm{Se}^{0}$ [5]. Protein bands were visualized by incubation in a $0.1 \%$ (by weight) solution of Coomassie brilliant blue R350 in 20\% methanol, $10 \%$ acetic acid, and $70 \%$ water (v:v:v) and destained in a solution of $10 \%$ acetic acid and 50\% methanol (v:v)

Dimethylselenide and dimethyldiselenide production. Culture bottles (125 ml; sealed with Teflon-lined stoppers) contained $50 \mathrm{ml}$ $\mathrm{HM}$ broth supplemented with $10 \mathrm{mM} \mathrm{NaNO} 3,30 \mathrm{mM} \mathrm{CH} \mathrm{CH}_{3} \mathrm{COONa}$, and $4 \mathrm{mM} \mathrm{Na}_{2} \mathrm{SeO}_{3} . \mathrm{Na}_{2} \mathrm{SeO}_{3}$ was filter sterilized, and other materials were sterilized by autoclaving. Inoculum was $5 \mathrm{ml}$ from log-phase culture. Cultures were incubated under $75 \mathrm{ml}$ air at $28^{\circ} \mathrm{C}$ and $100 \mathrm{rpm}$. On day 11 , samples from the headspace were analyzed [9].

Effect of tungstate and molybdenum on selenite reductase. All cells were incubated for 6 days at $28^{\circ} \mathrm{C}$ and $100 \mathrm{rpm}$ under air in sealed $125-\mathrm{ml}$ bottles containing $40 \mathrm{ml}$ TY media supplemented with $40 \mathrm{mM}$ $\mathrm{NaNO}_{3}$ and $4 \mathrm{mM} \mathrm{Na}_{2} \mathrm{SeO}_{3}$. In addition, three bottles received $10 \mathrm{mM}$ $\mathrm{Na}_{2} \mathrm{O}_{4} \mathrm{~W} \cdot 2 \mathrm{H}_{2} \mathrm{O}$; three received $10 \mathrm{mM} \mathrm{MoO}$; and three received no additional supplements. At the end of the incubation, cells and precipitated $\mathrm{Se}^{0}$ were spun at $23,000 \times \mathrm{g}$ for 20 minutes, and the pellet washed twice with $20 \mathrm{ml}$ deionized water and resuspended in $2 \mathrm{ml}$ $6.0 \%$ sodium hypochlorite (bleach) solution. The resuspended pellets were incubated at $30^{\circ} \mathrm{C}$ and $100 \mathrm{rpm}$ for 18 hours and then assayed for selenite and selenate derived from the oxidation of precipitated $\mathrm{Se}^{0}$.

Statistical comparisons. Mean $\pm \mathrm{SE}$ of the mean and $P$-value determinations were made using the Instat computer program (GraphPad Software Inc., San Diego, CA). Bootstrap values were computed by the MEGA 3.1 computer program [13].

\section{Results and Discussion}

On TY agar, colonies of N1 strain were circular, entire, convex, glistening, translucent, and amber in color. No strong odor was produced. Gram reaction by potassium hydroxide was negative. Colonies, approximately 2.1 $\mathrm{mm}$ in diameter, formed after 6 days of incubation. Microscopic examination showed that cells were rod, comma, or spiral shaped and motile. Biochemical tests show that N1 was positive for malic acid assimilation and negative for arginine dihydrolase, $\beta$-galactosidase, gelatinase, glucose and mannitol fermentation and oxidation, indole production, and urease. Cells grew on malic acid but not on $\mathrm{N}$-acetyl-glucoseamine, adipic acid, arabinose, capric acid, citrate, gluconate, glucose, maltose, mannose, manitol, or phenolacetic acid. Cells grew under both aerobic and microaerophilic (1\% oxygen) conditions. Colony sizes at 48 hours were largest $(0.87 \pm 0.04 \mathrm{~mm})$ when cells were grown under atmospheric levels of oxygen; cells grown with $1 \%$ oxygen had decreased colony sizes $(0.35 \pm 0.02 \mathrm{~mm})$.

The 16S rRNA gene (1535 bp) of the N1 strain was sequenced, compared with those in the National Institutes of Health BLAST (blastn) database, and a neighbor-joining tree was developed (Fig. 1). The N1 strain's 16S rDNA gene sequence clustered with those from Azospira oryzae, Dechlorosoma sp. and D. suillum. The literature suggests that $D$. suillum, described by Achenbach et al. [1], and A. oryzae, described by Reinhold-Hurek and Hurek [16], are the same species [18] and that $D$. suillum is a later synonym of A. oryzae. Sequence alignment showed that N1 has a $>99.9 \%$ identity with A. oryzae, an aerobic Proteobacteria often associated with plant roots [16]. Based on this sequence similarity and the biochemical and morphologic characteristics listed previously, I consider N1 to be an A. oryzae.

Dechlorosoma sp. Iso2, D. suillum, and D. agitatus all use perchlorate and chlorate as terminal $\mathrm{e}^{-}$donors [3]. Despite the close relationship that A. oryzae has with these (per)chlorate-respiring bacteria A. oryzae $\mathrm{N} 1$ was unable to use $\mathrm{ClO}_{3}{ }^{-}$as a terminal $\mathrm{e}^{-}$acceptor for growth under microaerophilic 


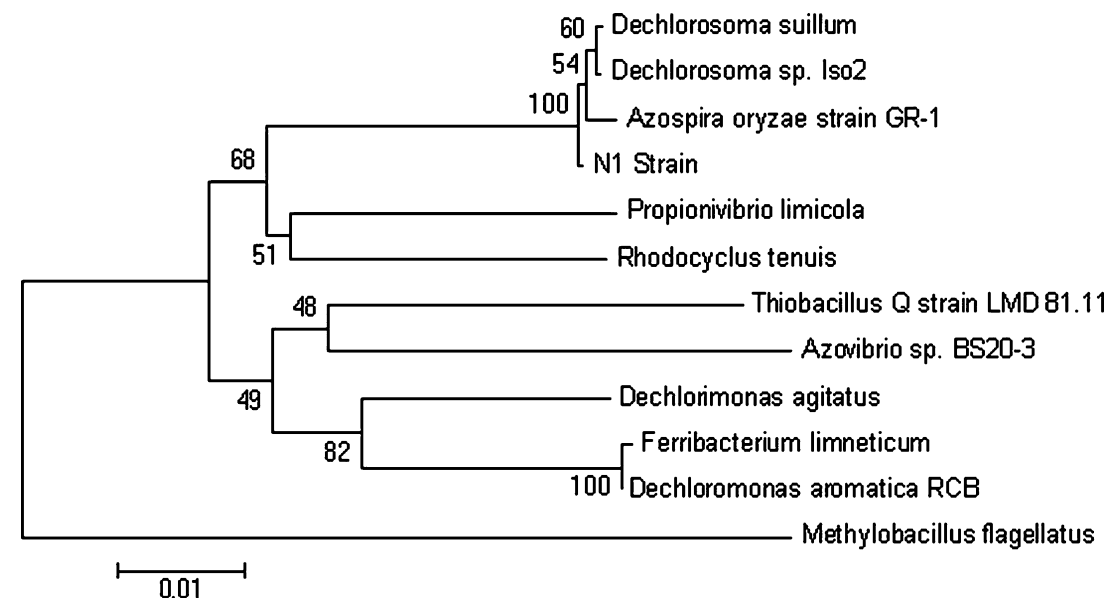

Fig. 1. Neighbor-joining tree showing the phylogenetic position of the $\mathrm{N} 1$ strain relative to related strains. Numbers at nodes indicate bootstrap value (500 replicates). Accession numbers are Azospira oryzae (AY277622), Azovibrio sp. (AF011349), Dechlorosoma sp. (AF170351), Dechlorosoma suillum (AF170348), Dechloromonas agitate (AF047462), D. aromatica (CP000089), Ferribacterium limneticum (Y17060), Methylobacillus flagellatus (DQ287787), Propionivibrio limicola (AJ307983), Rhodocyclus tenuis (D16208), and Thiobacillus Q (AJ289884). Scale bar indicates substitutions per site. conditions. Colonies of A. oryzae N1 grown on agar plates supplemented with chlorate were not significantly larger or smaller $(P>0.05)$ than those grown on media without chlorate, suggesting that chlorate does not serve as a terminal $\mathrm{e}^{-}$acceptor for growth for this organism under microaerophilic conditions. In contrast, colonies on plates with supplemental nitrate were larger $(P<0.05)$, showing that nitrate was used as a terminal $\mathrm{e}^{-}$donor (Table 1 ).

Aerobic growth of the A. oryzae N1 strain in HM broth was not visibly influenced by the presence of $\mathrm{NO}_{3}{ }^{-}, \mathrm{SeO}_{4}{ }^{-2}$, or $\mathrm{SeO}_{3}{ }^{-2}$ in the media, and no red color developed, indicating that $\mathrm{Se}$ oxyanions were not reduced to $\mathrm{Se}^{0}$ (Table 2). Under anaerobic conditions, $\mathrm{SeO}_{4}{ }^{-2}$ and $\mathrm{SeO}_{3}{ }^{-2}$ were both reduced to $\mathrm{Se}^{0}$, but growth as well as $\mathrm{SeO}_{4}{ }^{-2}$ and $\mathrm{SeO}_{3}{ }^{-2}$ reduction depended on the presence of $\mathrm{NO}_{3}{ }^{-}$(Table 2). Anaerobic cultures supplemented with $\mathrm{SeO}_{4}{ }^{-2}$ and $\mathrm{SeO}_{3}{ }^{-2}$, as sole terminal $\mathrm{e}^{-}$acceptors, failed to show growth or evidence of $\mathrm{Se}^{0}$ formation. The results showed that $\mathrm{N} 1$ can use oxygen or $\mathrm{NO}_{3}{ }^{-}$, but not $\mathrm{SeO}_{4}{ }^{-2}$ or $\mathrm{SeO}_{3}{ }^{-2}$, as terminal $\mathrm{e}^{-}$acceptors for growth. Use of $\mathrm{NO}_{3}{ }^{-}$as a terminal $\mathrm{e}^{-}$ acceptor did not result in the accumulation of $\mathrm{N}_{2} \mathrm{O}$, even when acetylene was present (data not shown), suggesting that the organism does not have a complete dissimilatory $\mathrm{NO}_{3}{ }^{-}$reductase system.

In this study, $\mathrm{SeO}_{4}{ }^{-2}$ and $\mathrm{SeO}_{3}{ }^{-2}$ were reduced to $\mathrm{Se}^{0}$ only when $\mathrm{NO}_{3}{ }^{-}$was present. However, $\mathrm{NO}_{3}{ }^{-}$was not required because Se oxyanions also were reduced to $\mathrm{Se}^{0}$ when $\mathrm{N} 1$ was grown without $\mathrm{NO}_{3}{ }^{-}$under microaerophilic (1\% oxygen) conditions (data not shown).

Selenium deposits. Microscopic examination revealed that granules, $0.25 \pm 0.04 \mu \mathrm{m}$ in diameter, were present in cultures of $\mathrm{N} 1$ cells grown in the presence of $\mathrm{Se}$ oxyanions but not in cultures grown in their absence. The granules were found both free in the media and
Table 1. Effect of chlorate on growth of A. oryzae N1 grown under microaerophilic conditions.

\begin{tabular}{ll}
\hline Growth media & Colony size $(\mathrm{mm})$ \\
\hline $\mathrm{TY}$ only & $0.56 \pm 0.07^{*}$ \\
$\mathrm{TY}+\mathrm{ClO}_{3}{ }^{-}$ & $0.44 \pm 0.04$ \\
$\mathrm{TY}+\mathrm{NO}_{3}{ }^{-}$ & $0.98 \pm 0.10$ \\
\hline
\end{tabular}

*Values are the mean \pm SEM of 8 to 10 replicate measurements. Colony size study $28^{\circ} \mathrm{C},<1 \% \mathrm{O}_{2}$, TY media supplemented with nothing, $10 \mathrm{mM} \mathrm{ClO}_{3}{ }^{-}$, or $10 \mathrm{mM} \mathrm{NO}_{3}{ }^{-}$

associated with cells and were uniform in their size and appearance (Fig. 2). Such particles have also been noted in cultures of other bacteria grown with Se oxyanions and have been identified as granules of $\mathrm{Se}^{0}$ [6].

Effect of selenate on cell morphology. Morphologically altered cells may result when bacterial cells are exposed to heavy metals, and elongated or filamentous cells may develop if cell division is inhibited. Cells of Salmonella heidelberg and Stenotrophomonas sp. exhibited greatly elongated cells when exposed to approximately $0.5 \mathrm{mM}$ selenite [15]. In contrast, $A$. oryzae N1 cells grown in the presence of $20 \mathrm{mM}$ selenate were slightly shorter, $1.1 \pm 0.06 \mu \mathrm{m}$ long for cells exposed to selenate versus $1.5 \pm 0.13 \mu \mathrm{m}$ long for cells not exposed to selenate $(P=0.0084)$.

Selenate reductase. Native gel electrophoresis of cellfree extracts of $\mathrm{N} 1$ revealed an activity, with a molecular weight of approximately $500 \mathrm{kD}$, that oxidized reduced MV when $\mathrm{SeO}_{4}{ }^{-2}$ was supplied as an $\mathrm{e}^{-}$acceptor (Fig. 3). An $\mathrm{SO}_{4}{ }^{-}$reductase that was clearly distinct from the activity observed with $\mathrm{SeO}_{4}{ }^{-2}$ was also detected on the gel. $\mathrm{No} \mathrm{NO}_{3}{ }^{-}$reductase activity was detected. These results demonstrate that A. oryzae N1 


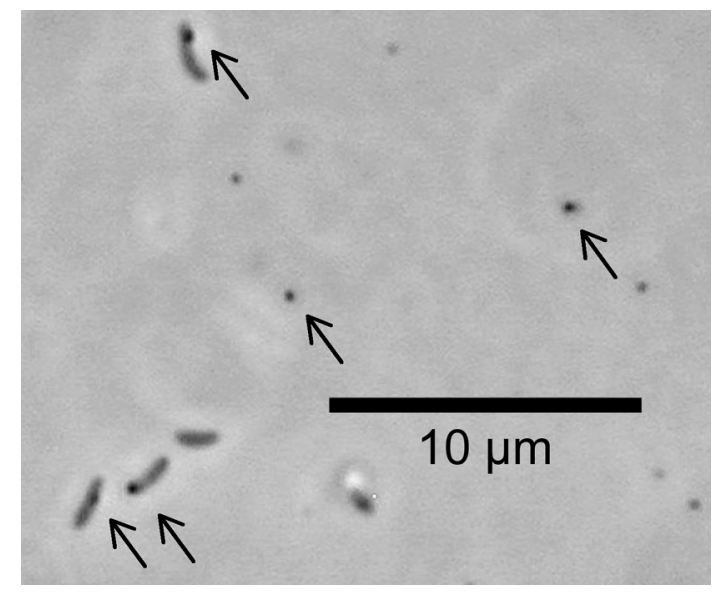

Fig. 2. Phase-contrast micrograph of $A$. oryzae $\mathrm{N} 1$ cells grown in the presence of $20 \mathrm{mM} \mathrm{SeO}_{4}{ }^{-2}$. Nanospheres of elemental red selenium appear as dark spots (arrows) associated with the cells and free in the medium.

has a high molecular weight $\mathrm{SeO}_{4}{ }^{-2}$ reductase that is clearly distinct from sulfate reductase.

Selenite reductase. Native gel electrophoresis of cellfree extracts also revealed the presence of a protein that oxidized reduced $\mathrm{MV}$ when $\mathrm{SeO}_{3}{ }^{-2}$ was present (Fig. 3). This activity, with a molecular weight of approximately $55 \mathrm{kD}$, was clearly distinct and much smaller than reductase activities observed with $\mathrm{SeO}_{4}{ }^{-2}, \mathrm{SO}_{4}{ }^{-}$, and $\mathrm{NO}_{2}{ }^{-}$as substrate and larger than activities noted with DMSO as substrate. DMSO reductase, an iron-sulfur molybdoenzyme, catalyzes the reduction of a number of compounds, and the DMSO reductase of Bacillus selenitireducens strain MLS10 has been shown to reduce $\mathrm{SeO}_{3}{ }^{-2}$ [2].

Culture studies have shown that $\mathrm{Se}^{0}$ formed as a red precipitate when $A$. oryzae $\mathrm{N} 1$ cells were incubated under microaerophilic conditions in TY broth supplemented with $\mathrm{SeO}_{3}{ }^{-2}$. However, the formation of this red precipitate was blocked when tungsten was incorporated into the media (Fig. 4). Chemically, tungsten resembles molybdenum, and its presence in culture media can result in the replacement of molybdenum by tungsten during protein biosynthesis, yielding inactive enzymes [17]. The inhibition of $A$. oryzae selenite reduction by tungsten suggests that a molybdenum-containing enzyme is involved in the process.

Dimethylselenide and dimethyldiselenide production. The reduction of selenium oxyanions by microorganisms can result in the production of volatile forms of organic selenium compounds. The most common form of organic selenium detected in the environment and the form most often produced by
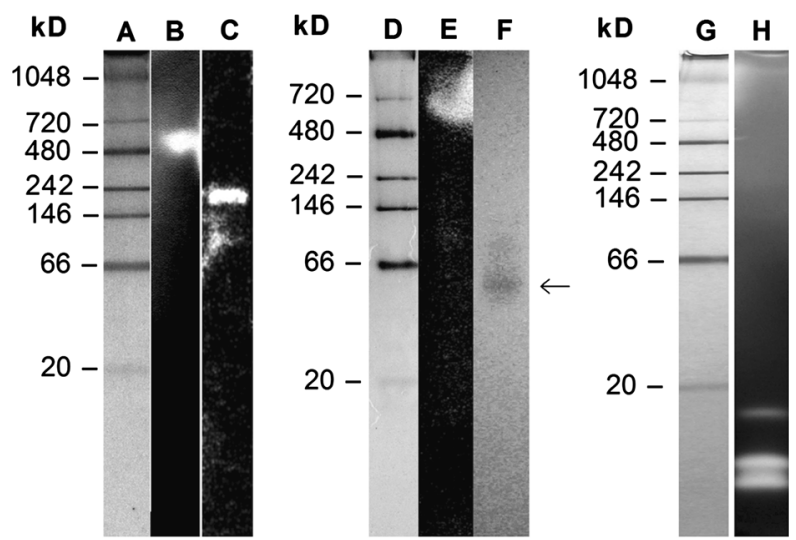

Fig. 3. Native polyacrylamide gel electrophoresis of A. oryzae strain N1 $\mathrm{SeO}_{4}{ }^{-2}$ and $\mathrm{SeO}_{3}^{-2}$ reductase activities. Molecular weight markers are shown in lanes $\mathrm{A}, \mathrm{D}$, and $\mathrm{G}$. Lane $\mathrm{B}=$ selenate reductase; lane $\mathrm{C}=$ sulfate reductase; lane $\mathrm{E}=$ shows nitrite reductase; lane $\mathrm{F}=$ selenite reductase (arrow); lane $\mathrm{H}=$ DMSO reductase activity. Selenate, nitrite, sulfate, and DMSO reductase activities appear as light spots of oxidized methyl viologen against a darker background. Selenite reductase activity (lane F) appears as a dark spot of precipitated Se against a lighter background. Proteins appear as dark bands against a lighter background.

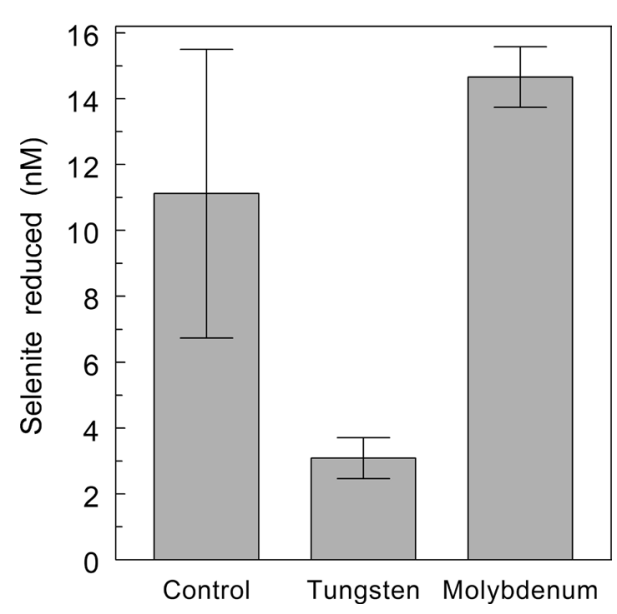

Fig. 4. Effects of tungsten and molybdenum on the accumulation of $\mathrm{Se}^{0}$ in cultures of $A$. oryzae $\mathrm{N} 1$ grown with $4 \mathrm{mM}$ selenite.

microorganisms is dimethylselenide (DMSe) [12, 19]. Also, dimethyldiselenide (DMDSe) may be produced by microorganisms. However, with A. oryzae N1 the reduction of the selenium oxyanions does not result in the production of detectable amounts of DMSe or DMDSe. The limits of detection for DMSe and DMDSe were $150 \mathrm{pg}$ and $50 \mathrm{ng}$, respectively, over cultures grown in sealed serum bottles. During the study, the concentration of $\mathrm{SeO}_{3}{ }^{-2}$ decreased from a starting concentration of $3.81 \pm 0.02$ to $3.38 \pm 0.01 \mathrm{mM}$, a change of $0.43 \mathrm{mM}$ or $11 \%$, and $\mathrm{Se}^{0}$ accumulated as a heavy red precipitate. 
Table 2. Growth and selenium oxyanion reduction by A. oryzae N1 under aerobic and anaerobic conditions and in the presence of various media supplements

\begin{tabular}{|c|c|c|c|c|c|c|}
\hline \multicolumn{7}{|c|}{ Media supplement } \\
\hline Growth conditions & None & $\mathrm{NO}_{3}^{-}$ & $\mathrm{SeO}_{3}{ }^{-2}$ & $\mathrm{SeO}_{4}^{-2}$ & $\mathrm{NO}_{3}^{-} \& \mathrm{SeO}_{3}^{-2}$ & $\mathrm{NO}_{3}{ }^{-} \& \mathrm{SeO}_{4}{ }^{-2}$ \\
\hline \multicolumn{7}{|c|}{ Growth (turbidity) } \\
\hline Aerobic & +++ & +++ & +++ & +++ & +++ & +++ \\
\hline Anaerobic & - & + & - & - & + & + \\
\hline \multicolumn{7}{|c|}{ Formation of red selenium precipitate } \\
\hline Aerobic & $\mathrm{n} / \mathrm{a}$ & $\mathrm{n} / \mathrm{a}$ & - & - & - & - \\
\hline Anaerobic & $\mathrm{n} / \mathrm{a}$ & $\mathrm{n} / \mathrm{a}$ & - & - & + & + \\
\hline
\end{tabular}

Growth and precipitate formation was estimated visually: $+++=$ heavy, $++=$ moderate,$+=$ slight, $-=$ none, $\mathrm{n} / \mathrm{a}=$ not applicable

\section{Conclusion}

A. oryzae $\mathrm{N} 1$, isolated from a, $\mathrm{SeO}_{4}{ }^{-2}$-reducing bioreactor, is capable of reducing $\mathrm{Se}$ oxyanions to $\mathrm{Se}^{0}$. The reduction results in the accumulation of insoluble $\mathrm{Se}$ nanospheres that are associated with the cells and found free in the medium. The reduction takes place under anaerobic as well as microaerophilic conditions but not under aerobic conditions. Two lines of evidence suggest that $A$. oryzae $\mathrm{N} 1$ does not use either $\mathrm{SeO}_{4}{ }^{-2}$ or $\mathrm{SeO}_{3}{ }^{-2}$ as $\mathrm{e}^{-}$acceptors for growth: (1) There was no visual evidence of growth when cells were grown under helium in Hungate tubes with $\mathrm{SeO}_{4}{ }^{-2}$ or $\mathrm{SeO}_{3}{ }^{-2}$ supplied as sole terminal $\mathrm{e}^{-}$acceptors. Growth was evident when nitrate was supplied as a sole $\mathrm{e}^{-}$acceptor (Table 2) and (2) no increase in cell numbers was observed with $\mathrm{SeO}_{4}{ }^{-2}$ when cells were grown under a trapped air atmosphere in Hungate tubes with and without $\mathrm{SeO}_{4}{ }^{-2}$ (data not shown). The enzyme associated with the reduction of $\mathrm{SeO}_{4}{ }^{-2}$ has a molecular mass of approximately $500 \mathrm{kD}$ and is clearly different from the activity that reduces sulfate. The enzyme associated with reduction of $\mathrm{SeO}_{3}{ }^{-2}$ by $A$. oryzae $\mathrm{N} 1$ appears to be a molybdenum-containing protein with a molecular mass of approximately $55 \mathrm{kD}$. It was distinct from the proteins associated with the reductions of $\mathrm{SeO}_{4}{ }^{-2}, \mathrm{SO}_{4}{ }^{-}, \mathrm{NO}_{2}{ }^{-}$, and DMSO.

\section{ACKNOWLEDGMENTS}

The author thanks Robin Montenieri and Cathy Cannon for expert technical assistance. Manufacturer and product names are given for readers' convenience and do not reflect endorsement by the United States government. This article was the work of United States government employees engaged in their official duties and is exempt from copyright.

\section{Literature Cited}

1. Achenbach LA, Michaelidou U, Bruce RA, Fryman J, Coates JD (2001) Dechloromonas agitata gen. nov., sp. nov. and Dechlorosoma suillum gen. nov., sp. nov., two novel environmentally dominant (per)chlorate-decreasing bacteria and their phylogenetic position. Int J Syst Evol Microbiol 51:527-533

2. Afkar E, Lisak J, Saltikov C, Basu P, Oremland RS, Stolz JF (2003) The respiratory arsenate reductase from Bacillus selenitireducens strain MLS10. FEMS Microbiol Lett 226:107-112

3. Bruce RA, Achenbach LA, Coates JD (1999) Reduction of (per)chlorate by a novel organism isolated from paper mill waste. Environ Microbiol 1:319-329

4. Buck JD (1982) Nonstaining (KOH) method for determination of Gram reactions of marine bacteria. Appl Environ Microbiol 44:992-993

5. Chiong M, Gonzales E, Barra R, Vasquez C (1988) Purification and biochemical of tellurite-reducing activities from Thermus thermophilus HB8. J Bact 170:3269-3273

6. Garbisu C, Ishii T, Leighton T, Buchanan BB (1996) Bacterial reduction of selenite to elemental selenium. Chem Geol 132:199204

7. Ganther HE, Levander OA, Sauman CA (1966) Dietary control of selenium volatilization in the rat. J Nutr 88:55-60

8. Greenberg AE, Clesceri LS, Eaton AD (eds) (1992) Standard methods for the examination of water and wastewater, 18th edn. Washington, DC: American Public Health Association, American Water Works Association and Water Environmental Federation, pp 82-93

9. Hunter WJ, Kuykendall LD (2004) Determination of dimethylselenide and dimethyldiselenide by gas chromatography photoionization detection. J Chromatogr 1038:295-297

10. Hunter WJ (2006) Removing selenate from groundwater with a vegetable oil based biobarrier. Curr Microbiol 53:244-248

11. Hunter WJ, Kuykendall LD (2006) Identification and characterization of an Aeromonas salmonicida (syn Haemophilus piscium) strain that reduces selenite to elemental red selenium. Curr Microbiol 52:305-309

12. Karlson U, Frankenberger WT Jr (1988) Determination of gaseous selenium-75 evolved from soil. Soil Sci Soc Am J 52:678-681

13. Kumar S, Tamura K, Nei M (2004) MEGA3: Integrated software for molecular evolutionary genetics analysis and sequence alignment. Brief Bioinform 5:150-163

14. Lund K, DeMoss JA (1976) Association-dissociation behavior and subunits structure of heat-released nitrate reductase from Escherichia coli. J Biol Chem 251:2207-2213

15. McCready RGL, Campbell JN, Payne JI (1996) Selenite reduction by Salmonella heidelberg. Can J Microbiol 12:703-714

16. Reinhold-Hurek B, Hurek T (2000) Reassessment of the taxonomic structure of the diazotrophic genus Azoarcus sensu lato and 
description of three new genera and new species, Azovibrio restrictus gen. nov., sp. nov., Azospira oryzae gen. nov., sp. nov. and Azonexus fungiphilus gen. nov., sp. nov. Int J Syst Evol Microbiol 50:649-659

17. Schmitz RA, Albracht SPJ, Thauer RK (1992) Properties of the tungsten-substituted molybdenum formylmethanofuran dehydrogenase from Methanobacterium wolfei. FEBS Lett 309:78-81
18. Tan Z, Reinhold-Hurek B (2003) Dechlorosoma suillum Achenbach et al. 2001 is a later subjective synonym of Azospira oryzae Reinhold-Hurek and Hurek 2000. Int J Sys Evol Microbiol 53:1139-1142

19. Zieve R, Ansell P, Young T, Peterson P (1985) Selenium volatilization by Mortierella species. Trans Br Mycol Soc 84:177179 